DOI: 10.24193/OJMNE.2019.29.03

\title{
THE CONCEPT OF EUROPEAN INTEGRATION IN THE EU-UKRAINE PERSPECTIVE: NOTIONAL AND INTERPRETATIVE ASPECTS OF LANGUAGE EXPRESSION
}

Olesia YEHOROVA, PhD

Associate professor, Sumy State University, Ukraine o.egorova@gf.sumdu.edu.ua Antonina PROKOPENKO, PhD

Assistant professor, Sumy State University, Ukraine a.prokopenko@gf.sumdu.edu.ua

Olena POPOVA, PhD

Associate professor, Sumy State University, Ukraine o.popova@gf.sumdu.edu.ua

\begin{abstract}
This article focuses on the concept of European integration (the EUROINTEGRATION-concept) as an integral part of the EU philosophy, policy, and overall worldview which is of prime interest for contemporary Ukraine that is currently undergoing a set of political, economic, and sociocultural transformations on its way to becoming a full member of the European Community. In particular, the study aims at revealing the ways in which the concept is perceived in the European integration discourses of the European Union and Ukraine. Since language is a tool for structuring human thoughts, we treat language as a point of entry for analyzing the world's construal in human cognition. Thus, both conceptual structure and content are analyzed on the basis of verbalized (language) externalization of the concept in English and Ukrainian languages and political and media discourses of the European Union and Ukraine. The study rests on the theory of a three-layered conceptual model that features notional-informative, figurative-associative, and interpretative layers. The paper discusses the contents of the notional and interpretative layers of the EUROINTEGRATION-concept. The lexicographic analysis backed by discursive interpretation helps to reveal convergences and divergences in the way European integration is conceptualized (understood and evaluated) in the European Union and Ukraine.
\end{abstract}

Keywords: EUROINTEGRATION-concept; conceptual layer; notional-informative layer; interpretative layer; European integration discourse.

\section{Introduction}

Since the turn of the century, globalization and Europeanization trends have been producing a great impact on Ukraine's socioeconomic transformations, its domestic and foreign 
policy-making. At the same time, each new cycle of political changes in the state makes the Ukrainians adopt new and effective forms of civic activism and self-identification. Such determination for change and the desire to at least partially get rid of the "post-Soviet" label have led to the emergence of such realities of modern Ukraine as eurodesign (European design), eurorenovation (European standards renovation), euroservice (European standards service), eurowindows (PVC windows), or euroyard (European patterns of improving rural territories). In the composites of this type, the prefix euro- acts as a cognitive "guarantor" of high quality and modernity, innovativeness and progressiveness that are characteristic of the "Western states" conventionally regarded by the Ukrainians as a common culture-historical and geographical area. At the same time, for an average citizen, say, of Germany or Croatia, the Ukrainian ideas of eurotires or eurowallpapers remain in the sphere of transcendence, as does the insight into what makes a decent lecturer's fee European in the minds of the Ukrainians.

The European aspirations of Ukraine contributed to the fast spread of the official EU terminology of eurolect in Ukrainian (e.g. eurobonds, eurozone, euromarket, European Commission, etc.). "The language of the EU" penetrated both political-economic and sociocultural discourses and contributed to shaping a specific type of discourse - the European integration discourse. At the heart of the European integration discourse of Ukraine lies the concept of European integration (the name usually contracted in Ukrainian to eurointegration, Ukr. євроінтеграція). The hypothesis of this article is that the source concept of European integration is differently conceptualized and externalized in the cultures and languages of the EU and Ukraine.

\section{Theoretical background}

Concepts represent significant, typical, and meaningful fragments of human experience (Karasik et al., 2005). The concept's significance for a particular culture is defined by the level of its externalization in the national language picture of the world (cf. the actualization of the SOULconcept in the West-European and East-European traditions and languages). Moving from the semantic content of words to the content of concepts, we proceed to the sphere of consciousness, to building models of the concepts which constitute the national concept-sphere and are the units of national culture (Popova and Sternin, 2007a).

According to the semantic-cognitive approach to conceptual analysis (V. Evans, V. Karasik, A. Prykhodko, M. Pimenova, Z. Popova, I. Sternin, etc.), concepts are organized 
according to the field principle (core::periphery) and may be described in terms of a three-layered model structured by the notional (informative), figurative-associative, and interpretative layers (or field components). The contents of these layers constitute heterogeneous "quanta" of knowledge about the concept. These we call conceptual features that get representation in language through different language means. The core of the concept and the by-core zone constitute the most apparent knowledge of the language speakers (speech community) about the fact of reality behind the concept. Other cognitive representations, normally added by culture, traditions, and people's collective and individual experiences, constitute the periphery. The elements of the periphery constitute the zone of transition to other concepts, thus, establishing links between the concepts within conceptual systems.

The notional layer of the concept exposes its informational content, covers the minimum of cognitive attributes that define the most significant differential features of the object of conceptualization, and excludes occasional, indirect, and evaluative meanings (Popova and Sternin, 2007b). In other words, the informational content of the concept is made up of a minimum set of cognitive features that render the most important and distinctive information about the object or phenomenon behind the concept.

According to Z. Popova and I. Sternin, the interpretative field is structured by the cognitive features that interpret the basic informative content of the concept or follow it, reproduce some inferential knowledge or evaluate it (Popova and Sternin, 2007a). The interpretative field of the concept has a heterogeneous structure and is made up of five zones: evaluative, utilitarian, regulating, sociocultural, and paremiological. These zones possess a special inner unity of content and cognitive features that cohere with them (Popova and Sternin, 2007a).

The present study focuses on the analysis of the conceptual content of the two aforementioned layers. However, within the semantic-cognitive approach, the cognitivists also single out the figurative-associative layer. It comprises sensual (perceptual) image, which is a product of reflecting objective reality through the human sensorium, and a set of conceptual metaphors that, according to the theory of cognitive metaphor of J. Lakoff and M. Johnson (Lakoff and Johnson, 2003), structure our thinking. The associative field of the concept comprises the cognitive features most frequently occurring in and extracted from a set of people's associations induced by sensual perceiving of the name of the concept. We believe that the analysis of these fields of the EUROINTEGRATION-concept in the EU-Ukraine perspective deserves independent 
research and description. Thus, further in this article, we confine ourselves to analyzing the notional-informative and interpretative layers of the concept.

\section{Methodology}

The notional content of any concept is exposed through a set of informative cognitive tokens that compose a definitional minimum of features which defines the kernel of the concept. Above all, the interpretation of the factual content of the EUROINTEGRATION-concept envisages performing component, etymological, and definitional analyses of its prime verbalizers - the concept's key names European integration in English and євроінтеграція (європейська інтеграція) in Ukrainian. Identifying the etymon that lies behind the core element of the composite helps define "the initial point of its semantic filling" (Kolesov, 1992, p. 39), to learn "the preliterate history of the concept" (Stepanov, 1997, p. 7).

As long as the informative content of many concepts is close to the definition of the key nomination of the concept (Popova and Sternin, 2007a, p. 77) and is conventionally fixed by lexicographic sources (Prykhodko, 2013, p. 22), we turn to interpreting the actual (up-to-date) meaning of the lexemes integration and інтеграція (as the core components of the compounds) and the source verbs from which they derived - to integrate and інтегрувати. For this, we address the modern explanatory dictionaries of English and Ukrainian (English Oxford Living Dictionaries (EOLD)), Macmillan English Dictionary (MED), Словник української мови (Dictionary of the Ukrainian Language, SUM) and Великий тлумачний словник сучасної української мови (Large Explanatory Dictionary of the Contemporary Ukrainian Language, VTSSUM) and study the corresponding entries. The application of componential analysis to the definitional texts helps define the semic composition of the lexemes and derive conceptual features of the words from the sets of semes that form sememes. These "elementary parts of sense" to be extracted in the definitional texts we call semantic summands. Each semantic summand in the sampling acquires its index of occurrence the value of which gives grounds for determining some conceptual features pertaining to the notional layer of the EUROINTEGRATION-concept.

Further reflections and interpretations engage the elements of discourse analysis of media sources. It is used mainly to study the interpretative layer. Discourse analysis is a method of text analysis based on the representation of discourse as a complex communicative phenomenon, "designating a particular way of talking about and understanding the world (or an aspect of the 
world)" (Phillips and Jørgensen, 2002, p. 1). According to Burton (2010, p. 13), the essence of a discourse is the meaning we have about its subject. So, the European integration discourse covers not only the mental space of the EU officials but also that of common Europeans and Ukrainians: how they understand its key concepts and perceive its values, how they represent them in language and communication, what the European integration means to the European cultures and Ukrainian one in particular.

We believe that the real 'image' of the concept imprinted in a particular culture may be ascertained only through the analysis of different discourses. Thus, the elements of discourse analysis are applied in this study to analyze how the EUROINTEGRATION-concept is featured in the related political and media discourses which to a great extent shape the everyday discourse. This analysis envisaged the conceptual interpretation of the discursive fragments taken from different Ukrainian and EU online newspapers, blogs, and other informational and political resources like InterPressNews, VoxEU.org, Mirror Weekly, Interfax-Ukraine, KyivPost, Ukrinform, Europe Blog, AZquotes site, Europe.eu etc.

\section{Results and discussion}

\section{Notional-informative layer}

According to its morphological structure, the concept's key names in both languages eurointegration and євроінтеграція - are products of compounding from the word-combinations European integration and європейська інтеграція with the second element as the core one.

The lexeme integration is a term of Latin origin with a high degree of internationalization (cf. integration in English, integración in Spanish, Integration in German, integracja in Polish, integrasyon in Turkish, integrointi in Finnish, etc.). According to Oxford Latin dictionary (OLD), the etymological profile of the Latinism integratio can be viewed as follows:

noun integratio - 'returning', 'restoring' > verb integro, integrare - 'to restore to the former condition', 'to renew'; 'to reinvigorate'; 'to take up anew', 'to resume', 'to renew'; 'to make whole, complete' > adjective integer 'not previously touched', 'fresh', 'not yet decided', 'open', 'unprejudiced', 'not exhausted by previous activity', 'intact', 'fresh', 'whole', 'complete', 'youthful', 'unimpaired by ill health or disease', 'unblemished' > particle in- 'un-' + verb tango, 
tangere - 'to touch', 'to make a mention of', 'to affect', 'to border on', 'to adjoin', 'to taste', 'to arrive at'.

Thus, the common proto-image that forms the cognitive basis of the Latin word is 'the absence of an act of sensual (mostly tactile) experience'. Over time, the semantics of the derivatives have broadened not only due to their entry into other lexico-grammatical classes of words but also due to the semantic development: 'not previously touched', 'intact', 'fresh', 'complete' $\rightarrow$ ability to acquire these features, ability to regenerate and renew.

The results of componential analysis of the lexemes integration/to integrate and інтеграція/інтегрувати (see Table 1) lead to the procedure of cognitive interpretation and defining a set of basic (core) conceptual features of the notional layer of the EUROINTEGRATION-concept. In both languages, integration is viewed as a 'process' of 'combining' 'separate units' into 'a whole'. It should be noted that only English presents a range of cognitive features vital to the proper interpretation of the European integration discourse. These are 'society', 'membership', 'participation', 'institutional character', 'desegregation', 'getting' or 'giving' certain rights and opportunities. Accordingly, the core component of the concept's name in English features a wider semantic spectrum and the notional layer serves a stable and valid basis for further associative or evaluative layers of the concept. Alongside, in Ukrainian, the notional content of the concept does not lay a proper foundation for figurative and interpretative fields, the constituents of which "stratify" in the process of the lexeme's functioning in discourse.

Table 1. Semantic Composition of Lexemes integration / to integrate and інтеграція / інтегрувати

\begin{tabular}{|l|c|c|c|c|c|}
\hline Semantic summands & SUM & VTSSUM & EOLD & MED & q \\
\hline $\begin{array}{l}\text { об'єднання / integrating, combining, } \\
\text { intermixing, connect, together }\end{array}$ & + & + & + & + & 4 \\
\hline $\begin{array}{l}\text { єдине ціле, повнота / a whole, full, } \\
\text { сотрletely }\end{array}$ & + & + & + & + & 4 \\
\hline $\begin{array}{l}\text { складається з (різних, окремих) частин / } \\
\text { single, segregated, another (thing) }\end{array}$ & & + & + & + & 3 \\
\hline
\end{tabular}




\begin{tabular}{|c|c|c|c|c|}
\hline $\begin{array}{l}\text { дія, процес, діяльність / action, process, } \\
\text { activity }\end{array}$ & + & + & + & 3 \\
\hline інституційність / institution, organization & + & & + & 2 \\
\hline система, організм / unit, system & + & & + & 2 \\
\hline $\begin{array}{l}\text { Люди, суспільство / people, group, society, } \\
\text { social }\end{array}$ & & + & + & 2 \\
\hline $\begin{array}{l}\text { членство, залучення, «включеність» } \\
\text { /membership, involved, participation }\end{array}$ & & + & + & 2 \\
\hline $\begin{array}{l}\text { становлення, набуття / becoming, come } \\
\text { into }\end{array}$ & & + & + & 2 \\
\hline $\begin{array}{l}\text { приведення в дію, надання / bring into, } \\
\text { make smb become }\end{array}$ & & + & + & 2 \\
\hline расовість / segregated, races, racially & & + & + & 2 \\
\hline $\begin{array}{l}\text { упорядкування, узгодження, координація } \\
\text { / regulation, coordination }\end{array}$ & + & & & 1 \\
\hline рівність / equal & & + & & 1 \\
\hline доступність / allowing to use & & & + & 1 \\
\hline великий / larger & & & + & 1 \\
\hline ефективність /effective & & & + & 1 \\
\hline зміна / change & & & + & 1 \\
\hline правила / rules & & & + & 1 \\
\hline
\end{tabular}

Source: own elaboration.

Back to the first component of the concept's name, the prefixes euro- and $\epsilon в p о-$, we focus on the semantics of their source lexemes European / європейський in English and Ukrainian.

In the case of English, three relevant online explanatory dictionaries prove strong systemic reference of the lexeme European to the EU:

1) Collins English Dictionary (CED) traces the reference to the EU indirectly (see meaning 5): 
European

1. Of or relating to Europe or its inhabitants.

2. Native to or derived from Europe.

European

3. A native or inhabitant of Europe.

4. A person of European descent.

5. A supporter of the European Union or of a political union of the countries of Europe or a part of it.

2) The English Oxford Living Dictionaries (EOLD) provide with references to geographical, geopolitical, demographic, and sociopolitical contexts where European is used as an adjective or a noun:

European

1. Relating to or characteristic of Europe or its inhabitants.

1.1 Relating to the European Union.

European

1. A native or inhabitant of Europe.

1.1 A national of a state belonging to the European Union.

1.2 A person who is committed to the European Union.

1.3 A person of European parentage.

3) MED offers equal references to geographical, ethnocultural, and geopolitical contexts of the lexeme's usage:

European

1. Relating to Europe, or its people or culture.

2. Relating to the European Union.

A completely different case is that of the Ukrainian language whose modern lexicographic sources do not suggest any systemic semantic reference of the lexeme європейський to the European Union. Even the online version of the renowned Dictionary of the Modern Ukrainian language (SUM), currently under revision of the experts from the Ukrainian Lingua-Information 
Fund of National Academy of Sciences of Ukraine, boils down to a conventional definition (both original and translated texts provided):

ЄВРОПЕЙСЬКИЙ, а, е. Прикм. до європейці і Європа // Такий, як у Європі, у європейців; власт. Свропі, європейцям. // Стос. до народів і держав Західної Європи; західноєвропейський. // Відомий усій Свропі.

EUROPEAN Adj. to the Europeans and Europe. // Such as in Europe, as the Europeans have; peculiar to the Europeans. // Applied to the peoples and states of Western Europe. // Known throughout Europe.

Thus, again, we evidence significant restrictions as to the semantic content of the concept's name at the notional (factual) level. The fact how often the concept of European integration is being "triggered" in every day, political, and media discourses of Ukraine proves that Ukrainian lexicographic science has been sluggishly responding to the dynamics of the sociopolitical processes of today and the demands of modern times. In our opinion, there already exist plenty of reasons (apart from geographic ones) to consider both geopolitical and sociocultural contexts to which the lexeme європейський usually refers at present. Without a systemic (lexicographic) fixation, the term євроінтеграція is unable to render the full spectrum of cognitive features born by the source term in English.

Table 2. Notional Conceptual Features of Concepts EUROINTEGRATION / СВРОІНТЕГРАЦІЯ

\begin{tabular}{|l|cl|ll|}
\hline & \multicolumn{2}{|l|}{ Ukrainian } & English & \\
\hline European & $\bullet$ & relates to: & $\bullet$ & relates to: \\
integration & - & Europe & - & Europe \\
& - & peoples / residents & - & the inhabitants of Europe \\
& of Europe / the Europeans & - & the European Union \\
& - & the European states & & of European origin \\
& - & Western Europe & & \\
& & & & \\
& & & & \\
\end{tabular}

\footnotetext{
${ }^{1}$ Somewhat obsolete but still active among some Ukrainians is the approach to interpret the semantics of the lexeme European by applying the historical-geopolitical principle: in the post-war era, 'European' has long referred to a
} 


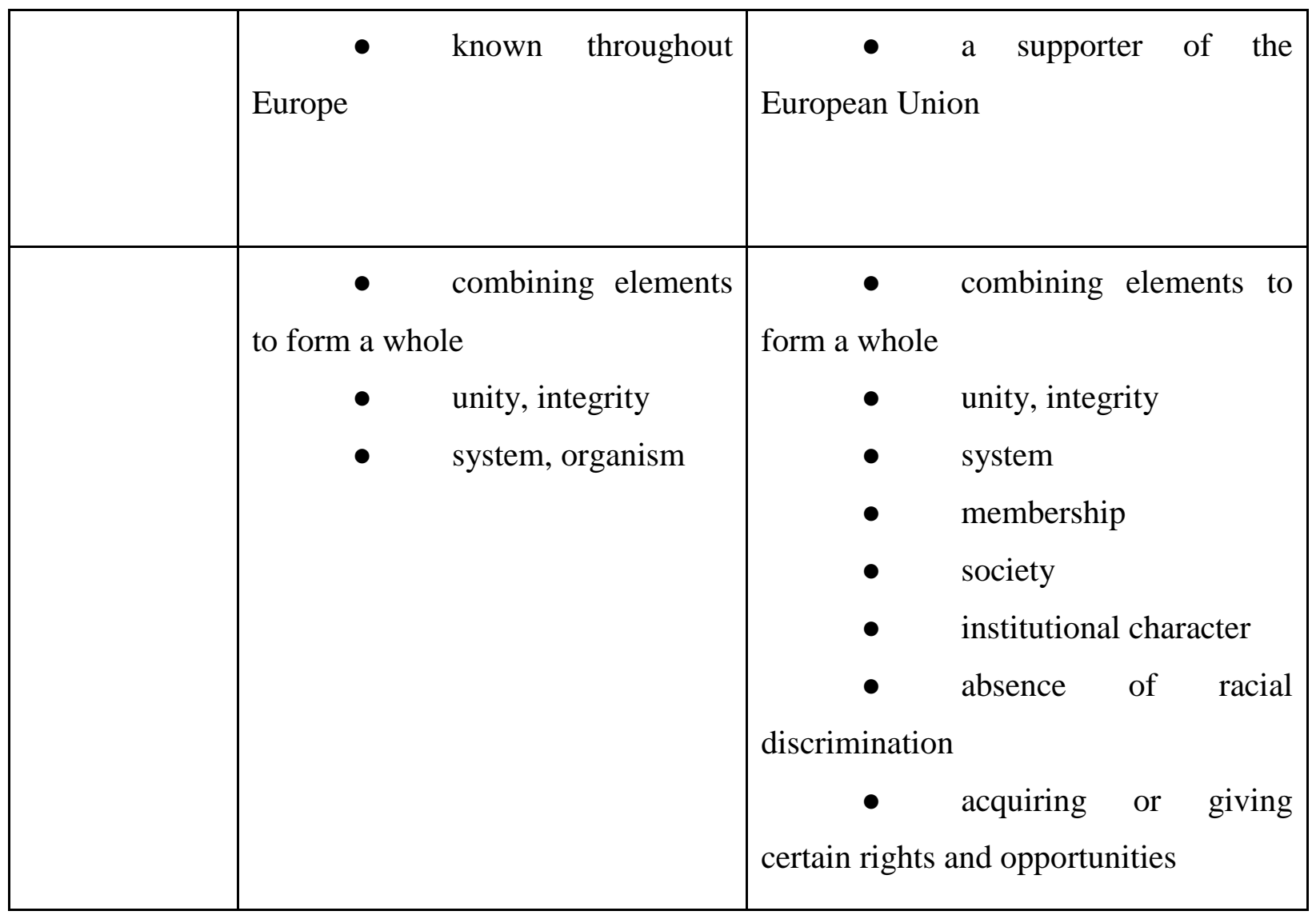

Source: own elaboration.

To sum up, the content of the notional layer of the concept in English and Ukrainian differs in volume: the English language is able "to encode" multiple conceptual features to be stored in the concept's informative layer. These features are seen as that factual (and the most general) "quanta" of information about the denotatum. The Ukrainian language, however, does not possess enough systemic sources to relevantly "decode" all this information. Thus, some notional information is perceived in the form of images, associations, or personal judgments rather than facts that build up corresponding layers in the concept's structure.

\section{Interpretative layer}

The notional layer structures the core but not the whole concept. The factual information conveyed by the concept's name is not enough for rendering the full content of the concept and

comparatively united sociocultural hub in Western Europe in terms of political demarcation between the liberal West and the communist East. 
shaping a cross-cultural profound understanding of the corresponding phenomenon (in our case, by the Ukrainians as compared to the EU citizens). Thus, we turn to analyzing the way the EUROINTEGRATION-concept gets actualized in speech (political and media discourses) and proceed to describing its interpretative field. The linguistic analysis of the European integration discourse enables revealing a wide spectrum of evaluative meanings of subjective natures at the levels of individual and collective (regional and national) conceptualization.

The postulated principles of the EU functioning actualize the foundations of the conceptual field "European citizenship" in the linguocultures of the EU citizens. They also feature such key concepts of sociopolitical, media, and everyday discourses as STABILITY, SECURITY, RELIABILITY, FREEDOM, etc. These concepts dominate the mental environment of the EU civil society which is the primary carrier of the corresponding European values.

A. Prykhodko states that the filling of the evaluative zone is conditioned by the very attitude of a person/a group towards the concept which must be positive for it rests on those spiritual impulses that awake in human consciousness due to the person's belonging to a particular ethnic and lingua-cultural group (Prykhodko, 2013). The evaluative zone of the interpretive field accumulates cognitive features that express general evaluation (good/bad), aesthetic (beautiful/not beautiful), emotional (pleasant/unpleasant), intellectual (clever/stupid), and moral (kind/wicked, legal/illegal, just/unjust, etc.) (Popova and Sternin, 2007a). We start by analyzing the filling of this zone in the English language discourse of the EU and consider several discursive fragments:

(1) European integration has proved phenomenally successful (Joergers et al., 2000);

(2) The idea of European integration and its implementation not only gave rise to an entirely new order in Europe - to be more exact, in Western Europe - but European history underwent a fundamental about-turn (Timuş, 2016);

(3) J. M. Barroso: We must respond and say that our values are a source of inspiration for many countries and I know that the Marie Skłodowska-Curie year has many students, from the South to the East of Europe and from outside Europe, who could directly testify to this (Barroso, 2011);

(4) In its turn, European integration is understood as a way of achieving important economic benefits, both at country level and individual level (Timuş, 2016); 
(5) And it is this process of European integration that is now being called into question by many people; it is viewed as a bureaucratic affair run by a faceless, soulless Eurocracy in Brussels - at best boring, at worst dangerous (Joergers et al., 2000);

(6) The European Union allows countries to do collectively what they could not do individually - that is to compete with countries like America and China on a global scale. This of course should in theory strengthen Europe's position globally and politically, but it also threatens to take away some of the power of individual governments. Many describe the European Union as "bureaucratic" and at times even un-democratic as many of the officials are appointed rather than elected (Europe Blog).

(7) As long as EU integration is seen as a project of the political elites and the rich, it will carry the seeds of its own destruction (Buti, 2017).

The foregoing fragments of political discourse feature the everlasting divergence of opinion on the role of the European integration. On the one hand, the success of the implementation of European standards in the domestic policies of the Member States is seen as a success of global and historic importance ("entirely new order in Europe", "fundamental about-turn"), as a way to economic prosperity ( "economic benefits"), as points of pride for Member States ("our values", "do collectively what could not do individually", "compete on a global scale”) and inspiration for the others. On the other hand, European integration is severely criticized because of being under the control of the rich and the elite who practice red tape ("bureaucratic", "Eurocracy") and malfunction ("seeds of own destruction") because of building utopian plans and threatening freedom.

Similar controversies in evaluating the denotatum behind the concept under study are traced in the European integration discourse of Ukraine:

(8) Eventually, European integration is about “improvement and wellbeing" but not today and exceptionally in case of reforms... In the long run, European integration is the most eligible and advantageous strategy for the development of Ukraine. Of prime importance here, as ever, the skills and goals of those who get this "fishing rod" (Holub, 2017);

(9) Thus, Ukraine's course to European integration is beyond question, although the road to Europe will be full of hardships, challenges, and disappointments. It will require us to develop a healthy sense of national egoism and economic and foreign policy forecasting. At the same time, 
it will make us abandon the illusions of getting some significant external support and the hopes for external participation and assistance in fast problem-solving inland (Bohdan, 2015).

The excerpts above prove that, in the context of Ukraine, European integration is an important economic factor for the country's further development and is positively valued (conceptual features "improvement", "wellbeing", "reforms", "eligible”, “advantageous", "strategy", "development", "fishing rod" etc.). The defined conceptual features evidence the desire of the Ukrainians to join the European Union as soon as possible, and thus get rid of the economic crisis. Meanwhile, the path of Ukraine towards economic prosperity in the EU gives rise to concerns which add to the negative evaluation of the concept (cognitive features "hardships", “challenges", “disappointments", “egoism”, “illusions”, “problem-solving”).

The utilitarian zone of the concept accumulates cognitive features that express utilitarian or pragmatic attitudes of people towards the concept's denotatum, as well as the knowledge related to the potential and peculiarities of its use for any practical needs (Popova and Sternin, 2007a). For defining the constituents of the zone, we turn to the fragments of political discourse all taken from Joergers et al. (2000):

(10) Robert Schuman: We must build the united Europe not only in the interest of the free nations, but also in order to be able to admit the peoples of Eastern Europe into this community if, freed from the constraints under which they live, they want to join and seek our moral support. We owe them the example of a unified, fraternal Europe. Every step we take along this road will mean a new opportunity for them;

(11) Accordingly, European integration process is seen as helping the newly emerging democracies of former USSR to find their own geopolitical place within the new European architecture;

(12) Of a particular importance are statements that claim that European integration process is the only one capable of helping the post-Soviet republics to escape Russian influence in the region... and ensuring the national statehood;

(13) Countries may wish to join the European Union (EU) to enjoy the benefits associated with membership. Some of the benefits include freedom to move to member countries, lowered product prices and better employee rights.

The discursive fragments show that in the English-language EU discourse, European integration is primarily associated with the countries of Eastern Europe - those with the Soviet 
past and presumably under Russia's strong influence. In this context, European integration is viewed as a single "lifebuoy for emerging democracies" which is expressed by lexical units exclusively marked by positive connotation: to admit, to free, to help, to ensure, a new opportunity, a way of achieving, benefits, freedom, lower (prices), better.

Zolkina (2013) reports the dynamics of public attitudes towards the European integration and the utilitarian significance of the EUROINTEGRATION-concept for common people in preEuromaidan Ukraine (2007-2013). According to the survey data, the main benefits of joining the EU for Ukraine would be free movement, raising the living standards, and easier access to European education. Alongside, the strongest fears of the Ukrainians in this connection were around the issues of emigration, immigration ("tides of foreigners, selling out the country"), and deterioration of relations with the CIS member states (Zolkina, 2013, pp. 7-9). Further findings, however, prove the disappearance of the polarity in integration priorities in the post-Euromaidan period: the Ukrainians are no longer significantly tormented by the choice between the EU and the Custom Union vectors (Zolkina and Haran, 2017, Public Opinion Survey of Residents of Ukraine, 2018). Among the core expectations of the Ukrainians from integrating into the EU are: access to the common market and border-free travel, security and stability, the EU financial aid, and support for democratic governance and rule of law (Public Opinion Survey of Residents of Ukraine, 2018, pp. 39-40).

Since media and political discourses are under prime consideration in this study, we turn to their fragments that help define the conceptual features of the concept's utilitarian zone in the Ukrainian language EU discourse which is vividly outlined by a kind of consumerism towards the denotatum. European integration is associated with the realization of quite important practical goals and is seen as an immediate tool for their achievement. However, of note should be the dynamics of "maturity" of expectations from those only Ukraine is interested in to those of panEuropean significance:

(14) [In the light of the 2004 enlargement of the European Union], along its borders, the EU will sick to create a zone of stability and prosperity with a particular interest in wealthy and environmentally sound Ukraine. Thus, our diplomats are expecting to obtain technological help and credit funds from the EU for the soonest implementation of the European standards of life in Ukrainian (Sokolova, 2003); 
(15) ... European integration is not merely a choice or a benchmark, it is a tool for strengthening democracy, economic growth, and modernization of the key economic spheres, for enhancing competitive strength of the Ukrainian manufacturers especially by supporting them in accordance with the anti-discrimination policy and world trade regulations ... (Holub, 2017);

(16) EU-Ukraine DCFTA, which is a part EU-Ukraine Association Agreement, will establish legal, economic, and institutional foundations for free movement of goods, services, capital, and, people. In the future, the extremely large and diversified EU market, removing foreign trade barriers, harmonization of regulatory principles and improvement of market institutions can become powerful catalysts for Ukraine's economic growth... (Bohdan, 2015).

The regulating zone of the interpretive field make up cognitive features that serve as "prescriptions" of what to be or not to be done in the sphere covered by the concept under consideration (Popova and Sternin, 2007a). Both in English and Ukrainian discourses, the filling of the regulating sector of the EUROINTEGRATION-concept is primarily featured through modal verbs and other constructions with the semantics of obligation. For example:

(17) ... we must put into place the last brick in the building of European integration, namely political integration (Joergers et al., 2000);

(18) Peter Mandelson: We've got to demonstrate why European unity and integration, our vast single market, our single currency, equip us with the strength to embrace globalization (AZquotes Site).

We should mention that the key aspects of EU-Ukraine integration are regulated by the provisions of the EU-Ukraine Association Agreement which also contributes to the exchange of information, experience, and best practices. The EU bodies provide Ukrainian authorities with numerous consultations, advice, and recommendations, which officially are not binding but in fact of directive nature for Ukraine:

(22) The European Union has reiterated the Ukrainian authorities should bring the bill on the High Anti-Corruption Court in line with the recommendations of the Venice Commission, according to an UNIAN correspondent in Brussels (KyivPost, 2018);

(23) Head of the EU Delegation to Ukraine Hugues Mingarelli stresses the need to create an anti-corruption court in Ukraine in accordance with the recommendations of the European Commission for Democracy through Law (Venice Commission) (Interfax-Ukraine, 2017). 
Thus, the analysis proves that the main conceptual features peculiar to the regulating zone are: “obligation”, “condition”, “need”, “recommendation”, “instruction”, “an algorithm”, etc.

Sternin and Rosenfeld claim that some conceptual structures have a symbolic zone that stores the information about the symbolic meaning which the conceptualized phenomenon acquired in culture (Sternin and Rosenfeld, 2015). The prime symbols of European integration are those of the European Union: the European Flag, the Anthem of Europe (performed purely instrumental due to a large number of official languages in the EU), the Motto of the European Union ("United in diversity"), and the Europe Day. Across the globe, the Europe Day is considered the day to celebrate and promote the EU's main ideas and values:

(24) Europe Day, held on 9 May every year, celebrates peace and unity in Europe. The date marks the anniversary of the historical 'Schuman declaration'. At a speech in Paris in 1950, Robert Schuman, the then French foreign minister, set out his idea for a new form of political cooperation in Europe, which would make war between Europe's nations unthinkable (Europa.eu).

Thus, the main features of the concept's symbolic zone in the English-language discourse of the EU can be defined as follows: "unity", "diversity", "peace", and "cooperation".

Since 2003, Europe Day has also been officially observed in Ukraine, though on the third Saturday in May. While, in the EU, it is a day of celebrating achievements, in Ukraine, it is still a day of expressing intentions:

(25) On its way to becoming a full member of the European community, 15 years ago, Ukraine introduced the tradition of celebrating Europe Day. The holiday is treated as a way to introduce and promote the EU values in Ukraine (BEYOND.UA).

Up to present, the flower and outcome of Ukraine's strivings for the European integration symbolize the events of 2013-2014, known as "Euromaidan" or "the Revolution of Dignity". For some, these developments in the heart of Ukraine became a turning point from "pseudoEurointegration" to the real eurointegrational shifts; for the others, they led to further frustration. Anyway, so far, Euromaidan remains the core symbol of the European integration in Ukraine sacredly referred to by the Ukrainian politicians when holding debates or delivering speeches.

Among the symbols of manifesting eurointegrational intentions of Ukraine is also the use of the European Flag. Since the days of the Revolution of Dignity, popularity gained a symbolic 
ritual of hoisting the EU flag at the Ukrainian government buildings and in other public places. On this account, O. Moisiienko says (Moisiienko, 2016):

(26) In Ukraine, there is an established practice of displaying the flag of the EU and the Council of Europe by the decisions of local councils. These decrees treat the use of the European symbols as a sign of public support of Ukraine's European integration course which is a top priority of both home and foreign policy of Ukraine. They also emphasize that Ukraine is a European country with a common European history and values and that it commits itself to promote and uphold these values.

All these facts lead to the assumptions that such conceptual features as "EU membership", "EU values", "sharing", and "Euromaidan" primarily constitute the symbolic zone of the EUROINTEGRATION-concept in the Ukrainian discourse.

Adjacent to the symbolic zone is the sociocultural zone which covers cognitive features that reflect the concept's association with everyday life and folk culture embedded in traditions, customs, music, history, sport, literary works, precedent texts, etc. (Popova and Sternin, 2007a). Thus, positive assessment of the EUROINTEGRATION-concept by the people gets revealed through the cultural heritage: cinematography (Winter on Fire: Ukraine's Fight for Freedom - a 2015 documentary film about the Euromaidan protests in Ukraine), music (Eurovision Song Contest; Killing Joke’s “European Super State”, Kateryna Buzhynska’s “Europe and Ukraine”, etc.), pieces of fine art (The Statue of Europe (Unity in Peace) in Brussels symbolizes peace achieved by means of the European integration) and art projects (Eurointegration through Art), numerous scientific popular works (Alina Polyakova's The Dark Side of European Integration; Peo Hansen \& Stefan Jonsson's Eurafrica. The United History of European Integration and Colonialism; Mary Farrell, Stefano Fella and Michael Newman European Integration in the $21^{\text {st }}$ Century, etc.), and others. However, the contents of this zone can be hardly analyzed within a comparative approach, so in this study, we limit ourselves to giving general remarks on it.

The paremiological zone is represented through a set of cognitive features externalized by the proverbs, sayings, and set expressions. In other words, these cover all the statements or ideas about the denotatum as reflected by the concept through the folk wisdom fund (Popova and Sternin, 2007a). Here we consider the examples from the English-language discourse first:

(27) There is an old saying in Brussels folklore: Integration is like riding a bicycle - if you don't keep going, you fall off (Emerson, 2015); 
(28) According to him [Janos Herman], Euro Integration has many preconditions. It is necessary to work intensively on fulfilling them. As he said, he does not like citing proverbs, but as the Chinese say, if you want to cross a bridge you should approach a river first. Therefore, this might be a matter of a generation, - the Ambassador added (InterPressNews, 2015).

In the given discursive fragments the European integration is associated with a purposive action that needs thorough prior preparation (precondition, approach ... first) because it is a lifelong commitment (keep going) which requires taking constant pains and does not forgive inactivity (fall off).

Needless to say, a long-term political and economic crisis in Ukraine let the ideas of Euroscepticism (both public and political) penetrate into the social and political discourse. From the general perspective of the European integration and following P. Kopecky and C. Mudde, the civil society of Ukraine (similar to that of the EU) can be stratified into the groups of Euroenthusiasts and Euro-sceptics as adherents of European integration and the groups of Europragmatists and Euro-opponents being hostile to the European integration processes (Kopecky and Mudde, 2002). Thus, in the context of Ukraine, the processes of European integration and deepening of socioeconomic and geopolitical crisis related to it in 2013 mostly got actualized through negative paremiological and allusive units:

(29) (about the relations in the context of the EU-Ukraine-Russia) Today, Ukraine is at the point described by Homer in the twelfth book of "The Odyssey". Scylla was dragging everybody approaching the terrible whirlpool. Charybdis sucked the sea terribly and spewed it out again (Bondarenko, 2013);

(30) When Mr. Yanukovych mentions European integration in his speeches, a Basarabian proverb comes to my mind “Why so poor? Because foolish! Why foolish? Because poor!” Mr. Yanukovych says, Ukraine is too poor to join the EU ... "Why is Ukraine so poor? Because of foolishness and lack of modernization! Why is it foolish and unmodernized? Because of its poorness!" How to break this vicious circle then?! There is no way out! (Vysotskyi, 2013);

(31) ..., the present dialogue between Brussels and Kiev resembles a well-known proverb: we are talking about "apples" (setting European prospects for Ukraine in the Association Agreement) and they are keeping on “oranges” or even on the lady-gardener [Y. Tymoshenko] who is ill-treated by the authority in power - the factor that deprives Ukraine of all its European prospects (Selskyi, 2011). 
Ukraine of 2013 was viewed as standing on the crossroad (apples or oranges) torn apart by the interested parties (Scylla and Charybdis) and incapable (foolish and poor) of making strongwilled decisions. However, in 2018, Ukraine is facing the future with confidence never to turn off the road and ready "to do in Rome what the Romans do":

(32) At present, the situation with the rights of LGBT persons reminds the Ukrainian proverb: "You never know what you can do till you try". Unlikely that the politicians take real care of the sexual minorities' rights, they rather realized that LGBT can't be thrown out of the “eurointegrational train”, otherwise it won't pass the EU's customs (Hloba, 2016);

(33) There is a saying: the dogs may bark, the wind may blow tomahawks, but the caravan, our Ukrainian caravan, moves on. In a week, on September 01, the EU-Ukraine Association Agreement enters into force and becomes a road map for our reforms. And there is only one road for us - a broad Euro-Atlantic autobahn that leads to our membership in the EU and NATO," stated the President (Ukrinform).

Thus, we face the dynamic development of the concept in the Ukrainian worldview and the sensitivity of the paremiological zone to the modification of the conceptual contents.

To sum up, within its interpretative field, the concept strongly features the core (evaluative, utilitarian, regulating) and the periphery (symbolic, sociocultural and paremiological) zones.

The study proves that the core of the interpretation field of the EUROINTEGRATIONconcept constitute utilitarian and evaluative zones. Backed by the real experience, certain knowledge in relation to European integration gets actualized in the EU discourse through language units with positive and negative connotations. The lack of such practical experience of "living in the EU" in the case of Ukraine explains the dominance of positive evaluations of the European integration; however, the way to this "secured life" seems extremely uneasy and stipulates negative connotations. In the English-language EU discourse, the regulating zone belongs to the core of the interpretative field whereas in the discourse of Ukraine it takes a by-core position: the rule and supremacy of law are still rather strivings than norms. The regulations of European integration in the English-language EU discourse are viewed as a task "to keep" and "to improve" whereas in Ukraine, they are seen as "to create", "to reform", and "to achieve".

The EU pays much attention to the sociocultural aspect of integration - the pledge of harmonious coexistence of nations, cultures, and religions within the community. The EU is proud of its toleration and language policies. It supports educational and scientific mobility and promotes 
its social values worldwide. In the context of Ukraine, these values have not been fully adopted yet. Thus, these cognitive features of the concept remain in the periphery zone of the EUROINTEGRATION-concept.

\section{Conclusions}

The EUROINTEGRATION-concept as the heart of the European integration discourse is a complex cognitive product of comprehending and interpreting the set of geopolitical, economic, and sociocultural processes in modern Europe. In the European integration discourse of Ukraine, the EUROINTEGRATION-concept is an abstract category of knowledge and practice, rather regarded not as a life philosophy of the society but as an ideological benchmark or a constructive goal that sets up priority vectors of Ukraine's development today.

The contrastive analysis of the conceptual content in both English-language and Ukrainianlanguage systems and EU discourses demonstrate essential divergences in conceptualizing and interpreting the phenomenon of the European integration. It means that European integration is differently represented and verbalized, and thus perceived by the EU and Ukrainian citizens. However, the predominance of positive associations and evaluations found in the Ukrainian political and media discourses of today catalyze the overall eurointegrational processes in Ukraine and make the EU closer to Ukrainians. At the same time, the EU context actualizes such EU realias as "unemployment", "loss of national identity", "outflow of skilled labor", "immigration", "refugees", "economic crisis", "high costs", "red tape", etc. whereas in the Ukrainian-language discourse of the EU, there is still little constructive criticism over the EU policies. To some extent, some prefer to see the world through rose-colored spectacles, some lack alternative sources of information, but to a greater extent, the Ukrainian society, having entered a new stage of political history, seems not to be ready so soon to part with the long-cherished ideas and aspirations and does not want to turn back to the recent past. Instead, Ukraine has not yet experienced living on the other side of the "Cold Curtain". People say the grass is always greener on the other side. So, Ukraine seems still to be ready to take risks. 


\section{Acknowledgement}

The study was conducted as part of the research project "Mechanisms of Civil Society Influence on Eurointegration Processes in Ukraine" (state registration number 0116U006811) financed by the Ministry of Education and Science of Ukraine.

\section{References}

1. AZQUOTES.COM, European integration quotes. [Online] AZQuotes Site. Available from: http://www.azquotes.com/quotes/topics/european-integration.html [Accessed 22/12/18].

2. BARROSO, J. (2011) Speech by President Barroso at the opening of the Academic Year 20112012 at the College of Europe (Natolin campus). [Online] Europa.eu: European Commission. Available from: http://europa.eu/rapid/press-release_SPEECH-11-617_en.htm [Accessed 17/03/19].

3. BEYOND.UA, Den Yevropy v Ukraini [Europe day in Ukraine]. [Online] Sait kulturnoistorychnoi platformy BEYOND.UA [Site of the cultural-historical platform BEYOND.UA]. Available from: http://beyond.ua/den-ievropi-v-ukrayini [Accessed 23/12/18].

4. BOHDAN, T. (2015) Yevrointehratsiinyi kurs Ukrainy: problemy, protyrichchia, perspektyvy [Eurointegration course of Ukraine: problems, contradictions, prospects]. Dzerkalo tyzhnia. Ukraina [Mirror of the week. Ukraine]. [Online] 29th May. Available from: http://gazeta.dt.ua/macrolevel/yevrointegraciyniy-kurs-ukrayini-problemi-protirichchyaperspektivi-_.html [Accessed 11/03/19].

5. BONDARENKO, K. (2013) Intehratsiina Odisseia Ukrainy: pomizh Stsilloiu ta Kharybdoiu [Integration Odyssey of Ukraine: between Scilla and Kharibda]. Ukrainska Pravda [The Ukrainian Truth]. [Online] 25th March. Available from: http://www.pravda.com.ua/columns/2013/03/25/6986369/view_print [Accessed 21/12/18].

6. BURTON, G. (2010) Media and society: Critical perspectives. 2nd ed. Maidenhead: Open University Press.

7. BUTI, M. and PICHELMANN, K. (2017) European integration and populism: Addressing Dahrendorf's. [Online] VoxEU.org - CEPR's policy portal. Available from: http://voxeu.org/article/european-integration-and-populism-addressing-dahrendorfs-quandary [Accessed 22/12/18]. 
8. CENTER FOR INSIGHTS IN SURVEY RESEARCH (2018) Public Opinion Survey of Residents of Ukraine (2018). [Online]. Available from: https://www.iri.org/sites/default/files/june_2018_national_survey.pdf [Accessed 17/03/19].

9. EMERSON, M. (2015) All the ingredients of a nightmare scenario are being assembled. Is European integration in trouble? A symposium of views. The International Economy. Fall. 13.

10. EU insists on creation of Anti-Corruption Court in Ukraine in line with Venice Commission's recommendations - Mingarelli. [Online] Interfax-Ukraine. Available from: https://en.interfax.com.ua/news/general/466310.html [Accessed 23/12/18].

11. EUROPA.EU, Europe day 2017. [Online] Europa.eu: Official website of the European Union [run by The Directorate-General for communication]. Available from: https://europa.eu/european-union/about-eu/symbols/europe-day_en [Accessed 22/12/18].

12. EUROPEWORD.COM, European Union pros and cons. [Weblog]. Europe Blog. Available from: http://www.europeword.com/blog/europe/european-union-pros-and-cons [Accessed 21/12/18].

13. EVANS, V. (2009) How words mean: Lexical concepts, cognitive models, and meaning construction. Oxford: Oxford University Press.

14. HLOBA, B. (2016) Niderlandskyi referendum ta LHBT v Ukraini - koly prava staiut vahomymy [Netherlands referendum and LGBT in Ukraine - when the rights become important]. Yevropeiska Pravda [The European Truth]. [Online] 3rd February. Available from: https://www.eurointegration.com.ua/ukr/experts/2016/02/3/7044301 [Accessed 23/12/18].

15. HOLUB, M. (2017) Nove zhyttia yevrointehratsii: strybok u nevidome chy zabih $\mathrm{z}$ pereshkodamy [A new life of European integration: a leap into an unknown or obstacle race]. Yevropeiska Pravda [The European Truth]. [Online] 25th January. Available from: http://www.eurointegration.com.ua/experts/2017/01/25/7060602 [Accessed 21/12/18].

16. INTERPRESSNEWS, Janos Herman answers question on EU integration with a Chinese proverb. [Online] InterPressNews. Available from: http://www.interpressnews.ge/en/politicss/68511-janos-herman-answers-question-on-euintegration-with-a-chinese-proverb.html?ar=A [Accessed 21/12/18]. 
17. JOERGERS, C., MENY, Y. and WEILER, H.H. J. (eds.) (2000) From confederacy to federation - Thoughts on the finality of European integration: Speech by Joschka Fischer al the Humboldt University in Berlin, 12 May 2000. Florence; Cambridge: Robert Schuman Centre for Advanced Studies, European University Institute, Harvard Law School.

18. KARASIK, V., PIMENOVA, M. and POPOVA, Z. (eds.) (2005) Vvedenije v kognitivnuju lingvistiku [Introduction to cognitive linguistics]. Kemerovo: Kuzbassvuzizdat.

19. KOLESOV, V. (1992) Kontsept kultury: obraz - ponyatiye - simvol [The concept of culture: image - notion - symbol]. Vestnik Sankt-Peterburgskogo universiteta [Saint Petersburg university journal], 2 (2), pp. 3-40.

20. KOPECKÝ, P. and MUDDE, C. (2002) The two sides of Euroscepticism: Party positions on European integration in East Central Europe. European Union Politics, 3 (3), pp. 300-303.

21. LAKOFF, G. and JOHNSON, M. (2003) Metaphors we live by. Chicago: The University of Chicago Press.

22. PHILLIPS, L. and JØRGENSEN, M. (2002) Discourse analysis as theory and method. London: Sage Publications.

23. POPOVA, Z. and STERNIN, I. (2007a) Kognitivnaya lingvistika [Cognitive linguistics]. Moscow: AST "Vostok-Zapad".

24. POPOVA, Z. and STERNIN, I. (2007b) Semantiko-kognitivnyj analiz jazyka [Semantic and cognitive analysis of language]. Voronezh: Istoki.

25. PRYKHODKO, A. (2013) Contsepty i contseptosystemy [Concepts and conceptual systems]. Dnepropetrovsk: Belaya Ye.A.

26. SELSKYI, B. (2011) Na horodi buzyna, a v Kyievi titka [It's a cock and bull story]. Gazeta.ua. [Online] 17th November. Available from: https://gazeta.ua/articles/politics/_na-gorodibuzina-a-v-kiyevi-titka/410240?mobile=true [Accessed 22/12/18].

27. SOKOLOVA, M. (2003) Rozshyrennia YeS: pliusy ta minusy dlia Ukrainy [Enlargement of the EU: pros and cons for Ukraine]. Day.kyiv.ua. [Online] 5th November. Available from: https://day.kyiv.ua/uk/article/den-ukrayini/rozshirennya-ies-plyusi-ta-minusi-dlya-ukrayini [Accessed 09/03/19].

28. STEPANOV, Y. (1997) Konstanty: Slovar russkoy kultury [The constants: Dictionary of Russian culture]. Moscow: Shkola "Yazyki russkoy kultury". 
29. STERNIN, I. and ROSENFELD, M. (2015) Slovo i obraz [Word and image]. Moscow-Berlin: Direkt-Media.

30. TIMUŞ, N. (2016) The Perception of the EU and European integration in the East European neighbourhood. In: “ECPR Conference”, Prague, September 2016. [Online] Available from: https://ecpr.eu/Filestore/PaperProposal/f242b380-6e19-4b89-a1b9-15fb56758854.pdf [Accessed 22/12/18].

31. UKRINFORM, Poroshenko pro yevrointehratsiiu i chlenstvo v NATO: Sobaky breshut, a nash karavan ide [Poroshenko on Eurointegration and NATO membership: Dogs are lying, and our caravan moves on]. [Online] Ukrinform. Available from: https://www.ukrinform.ua/rubricpolytics/2292289-porosenko-pro-evrointegraciu-i-clenstvo-v-nato-sobaki-bresut-a-naskaravan-ide.html [Accessed 23/12/18].

32. UNIAN (2018) UNIAN: EU says Ukraine's Anti-Corruption Court bill should be in line with Venice Commission's recommendations. KyivPost. [Online] 18th January. Available from: https://www.kyivpost.com/ukraine-politics/unian-eu-says-ukraines-anti-corruption-court-billline-venice-commissions-recommendations.html [Accessed 23/12/18].

33. VYSOTSKYI, I. (2013) Populiarnyi anekdot na temu dnia [A popular joke of the day]. [Weblog]. Derzhava ta Suspilstvo: Bloh Ihoria Vysotskoho [State and Society: Igor Vysotsky's blog]. 1st December. Available from: http://derjawaua.blogspot.com/2013/11/blogpost_30.html [Accessed 11/03/19].

34. ZOLKINA, M. (2013) European Integration of Ukraine: Experience of Yesterday for Development of Tomorrow. Informational \& Analytical Bulletin. Public Opinion, (13), pp. 113.

35. ZOLKINA, M. and HARAN, O. (2017) Changes in the Foreign Policy Orientations of Ukrainians after the Euromaidan: National and Regional Levels. In: HARAN, O. and Yakovlyev, M. (eds.) Constructing a Political Nation: Changes in the Attitudes of Ukrainians during the War in the Donbas. Kyiv: Stylos Publishing, pp. 111-131.

\section{Dictionaries}

1. $C E D=$ Collins English Dictionary. [Online] Available from: https://www.collinsdictionary.com $\_$Accessed 22/12/2018]. 
2. $E O L D=$ English Oxford Living Dictionary. [Online] Available from: https://en.oxforddictionaries.com [Accessed 22/12/2018].

3. $\mathrm{MED}=$ Macmillan English Dictionary. [Online] Available from: http://www.macmillandictionary.com [Accessed 22/12/2018].

4. OLD = GLARE, P.G.W. (ed.) (1968) Oxford Latin Dictionary. XXIII. Oxford: Clarendon Press.

5. SUM = Slovnyk Ukraynskoi Movy Online [The Ukrainian language dictionary] (Vol 1-8). [Online] Available from: http://services.ulif.org.ua/expl/Entry/index?wordid=1\&page=0 [Accessed 22/12/2018].

6. VTSSUM = BUSEL, V. (ed.) (2005) Velykyi Tlumachnyi Slovnyk Suchasnoi Ukrainskoi Movy [The great explanatory dictionary of modern Ukrainian language]. Kyiv - Irpin: VTF "Perun". 